\title{
Contemporary Challenges of Malaysia Halal industry
}

\author{
Rahman bin Abdullah \\ Universiti Teknologi MARA,
}

UiTM Terengganu, 23000, Dungun, Terengganu

Harnizam Zahari

Universiti Teknologi MARA,

UiTM Terengganu, 23000, Dungun, Terengganu

Nik Adnan Nik Mat

Universiti Teknologi MARA,

UiTM Terengganu, 23000, Dungun, Terengganu

Razlan Adli Zain

Universiti Teknologi MARA,

UiTM Terengganu, 23000, Dungun, Terengganu

\author{
Nazarudin Derani \\ Universiti Teknologi MARA,
}

UiTM Terengganu, 23000, Dungun, Terengganu

\author{
Azahar Adzmy \\ Universiti Teknologi MARA, \\ UiTM Terengganu, 23000, Dungun, Terengganu \\ Mohamed Muneer Samsudin \\ Universiti Teknologi MARA, \\ UiTM Terengganu, 23000, Dungun, Terengganu \\ Radzuan Noor Armia \\ Universiti Teknologi MARA, \\ UiTM Terengganu, 23000, Dungun, Terengganu
}

\begin{abstract}
Halal market has been growing for the past couple of decades. The growth has been spurred by the demands of the Muslims society worldwide, the potential market it shows, the government support and initiatives, the private sector resourcefulness and the increase knowledge and awareness of the Muslims society and the Non-Muslims worldwide. However, although Malaysia has taken a lot of initiatives in ensuring halal industry grows substantially, Malaysia's governing bodies and the private sector needs to be aware of the challenges the Halal market needs to face in terms of fulfilling the consumer acceptance, religious acceptance, health and convenience and economic acceptance. A proper reasoning and understanding of the halal market and conditions will enable Malaysia to take the halal market to a more substantial level without offending or disregarding any factors in the first place.
\end{abstract}

Keywords:Halal, religion, consumer acceptance, Health, convenience, economics, Jhatka 


\section{INTRODUCTION}

The market for halal products (permissible products according to Islamic Law or Sharia) in ASEAN countries has been gauged to be US $\$ 46$ billion per year and worldwide US $\$ 150$ billion (Fisher, 2012). The Malaysian Halal market is growing at a fast pace either in terms of exports or imports. The response received for halal food has been on the rise together with the Muslims increase knowledge which constitutes about $60.4 \%$ of the Malaysian population. There are 16 million Muslims consumers between the age of 16-64 years old seeking halal food that also fits into their taste and demands (Ariffin, 2007). Currently, the local Halal industry is contributing less than $2 \%$ of the gross domestic product but it is expected to increase to about 5.8\% by 2020 (Povera, 2010). In 2017, The Deputy Prime Minister, in his opening address announce the local halal industry contributed $7.5 \%$ to Malaysia's Gross Domestic product, surpassing the target set for 2020. This is a positive indication showing an escalating increase of the Halal industry in Malaysia.

At the same time, In terms of halal accreditation, there are more than 300 bodies globally offering Halal certification but only $15 \%$ are recognized by JAKIM, Department of Islamic Development Malaysia, and Malaysian halal certification body (S,. Mahiah., H.Faridah.,M. Rosidah., \& N.A Rahman, 2014) . In 2003, 44.1\% of the SMEs manufacturing total output is from the food and beverage products which amount to 84.4 billion (Ariffin, 2007). There are over 33000 companies - food and non-food - certified by JAKIM currently (Ariffin, 2007). Malaysia's Halal certification is recognized worldwide among Muslim and Non-Muslim countries, which is ISO compliance developed by the Department of Standard Malaysia. The standard complies with international standards such as Good Manufacturing Practice (GMP) and Good Hygiene Practice (GHP) (S. Mahiah., H.Faridah, M. Rosidah., \& N.A Rahman, 2014). As such, it is widely acknowledged that the system and procedures of halal in Malaysia is warmly received by other Halal markets.

Malaysia also has a balanced knowledge of both Islamic tenets and other areas including technological development and sciences, particularly food sciences, biochemistry, and microbiology as well as in business management. Department of Islamic Development Malaysia (JAKIM) has resumed the responsibility as the Halal Certification body effective from 1st August 2009. The Halal Directory features companies which are registered with MATRADE and have products which are certified Halal (MATRADE, 2011).

In addition to that, Malaysia's strengths as the Halal hub as highlighted by Ariffin (2007) include global recognition of JAKIM Halal certification and auditing, special tax incentives for Halal food production, double tax deduction of expenses for Halal certification, collaborating with international retailers \& brands, Halal cold storage \& Halal express facilities, Port Klang Free Zone for Halal products fast-tracked Halal certification approvals and well-connected routes worldwide (S. Mahiah., H.Faridah, M. Rosidah., \& N.A Rahman, 2014)

All these development has cemented Malaysia as one of the major players in the halal international market and it is growing at a very positive pace. However, it is imperative for Malaysia to also acknowledge the challenges ahead of Malaysia's progress in the halal industry, and Halal food and beverages industry, to be more specific.

\section{LITERATURE REVIEW}

Halal in the Quran means lawful or permitted, hence Halal food is defined as permissible food that can be consumed with no doubt. According to Marzuki, Hall, and Ballentine (2011), Muslims must adhere to the Halal food standards and abstain from taking the prohibited food (haram). Eliasi and Dwyer (2002) explained that food is considered Halal or Haram by looking 
at the whole food chain. The food is Haram if the source is also Haram and has potential harm to the mind, body, and soul of a person. There are foods that fall between the Halal and Haram, regarded as Mashbuh. These foods may contain harmful substances that are disguised as healthy. Halal food is often associated with healthy food. Understanding the factors influencing market acceptance on Halal food is crucial to further describe the reasons behind the acceptance (N.M, Vloreen. Ardiana Mazwa Raudah binti Amir Abdullah, Siti Nurazizah binti Mohamad Ismail, 2014)

Lampila and Lahteenmaki (2007) agreed that consumer acceptance is often the key to success as far as food processing method is concerned. The general guidelines in Islam state the specific motives behind the Halal concept. Apart from religious value, the motives also include to preserve life, to safeguard future generations, and to maintain self-respect and integrity (Muhammad, Norhaziah, Nuradli and Hartini, 2007). The concept of Halal today is beyond religious value. The rising concern on health among consumers today is an advantage for Halal food producers, simply because health concern in food consumption basically shares the same value with the Halal concept. The concept of being healthy means being watchful over what is taken into the body, on the cleanliness of the food, the source of the food and also the method of handling and preparing the food. The main reason is to minimize any harmful effects to the body.

Market acceptance on Halal food could be due to several determinants. It is believed that consumers accepted a product when they have the intention to use, have used the product and continue using it. Consumers respond positively and accept products with high quality. In terms of food, quality is defined by its cleanliness and freshness. In order to achieve this, food processing methods are vital in sustaining the cleanliness and freshness of the food and directly affect the nutritional quality of food consumed. Food quality can also be used to determine food safety (Vloreen, Ardiana \& Siti Nurazizah, 2012). Grunert, Hartvig, Larsen, Madsen, and Baadsgraard (1996) divided quality dimensions for food into four classifications which are hedonic, health-related, and convenience related and process related. They added, "Hedonic quality is related to sensory pleasure and is therefore mainly linked to taste, smell, and appearance. Health-related quality is concerned with ways in which consumption of the product will affect consumer's physical health. Convenience related quality is related to the time and effort which has to be expanded while buying, storing, preparing and consuming the product". Hence, the ability of any producer or marketer to relate or meet the demands of Muslims consumers in terms of its health benefits, hedonics values, and convenience quality, would be able to attract the Muslims market in general.

On the other hand, the acceptance of other religion in relation to halal products, processes, and quality will ensure the expansion of its market in the future. In order to do so, many previous works have mentioned positively the acceptance of other religious groups about Halal products. However, a deep insight in relation to religion should be taken so that we are better able to understand the real situation.

\section{Religion}

Religiosity is a multidimensional and complex concept thus definitions may vary based on the assessed religion. It is mainly used in measuring the religious commitment and devoutness of individuals. According to McDaniel and Burnett (1991, pg 1010), religiosity is "a belief in God accompanied by a commitment to follow principles believed to be set by "God", whereas Geser (2009) citing other scholars such as King (1967) offers a more comprehensive definition, suggesting that religiosity is a complex, multidimensional construct that encompasses cognitive values and beliefs, affective feelings of spirituality and commitment and behaviors 
such as prayers and church attendance. As such religiosity refers to the extent to which a person is devoted, committed and adhere to religious values and beliefs: as a continuous rather than a distinct variable (Beit-hallahmi and Argyle, 1997). It is not a uni-dimensional concept (King and Hunt, 1972, Abou-Youssef et al, 2015), but rather a multi-dimensional and complex construct that relates to several elements of religion which in turn affect how people live their lives in a number of ways. These elements include beliefs, values and attitudes, knowledge, experience, and practices that affect our daily activities (O'Connell, 1975, Abou-Youssef et al, 2015) (Abdulrazak, Rula M.AI, Ayantuji Gbadamosi, 2017). Religiosity commitment plays an important role in people's lives by shaping their beliefs, knowledge, and attitudes, regardless of their religious orientations (Muslims, Christians, Buddhist, and others). As a result, these religious commitments and beliefs influence the feelings and attitude of people towards consumption (Jamal, 2003).

Although Halal food and beverages are quite well accepted by the majority of Non-Muslims, due to its better hygiene preparations, quality, and availability, it must be acknowledged that certain religion is prohibited from consuming Halal food especially its meat. The Sikh population, in particular, are prohibited from consuming the halal meat.

\begin{abstract}
"And one Semitic practice clearly rejected in the Sikh code of conduct is eating the flesh of an animal cooked in a ritualistic manner; this would mean kosher and halal meat. The reason again does not lie in religious tenet but in the view that killing an animal with a prayer is not going to ennoble the flesh. No ritual, whoever conducts it, is going to do any good either to the animal or to the diner. Let the man do what he must to assuage his hunger. If what he gets, he puts to good use and shares with the needy, then it is well used and well spent, otherwise not." (Singh, I. J., Sikhs and Sikhism)
\end{abstract}

Their own method of slaughtering produces "Jhatka" meat, specifically referring to meat obtained by slaughtering the animal with a single stroke, so as to minimize torture without any ritual or prayers. The Sikh population is around 27 million worldwide, which constitutes about $0.39 \%$ of the world population. Although in Malaysia, the Sikh population is a minority, it needs to be addressed that the Sikh is a community that needs to be respected of their choices and religious adherence and thus, the halal producer and provider should not try to market its product towards them. At the same time, many vegans and Hindus have the tendency to follow the Sikh practice of consuming meat and thus, they prefer "Jhatka meat" from Halal meat. This is another condition that needs to be addressed by the Halal producer, manufacturer, marketers and retailers so as not to offend these group of people by making an aggressive effort of marketing and selling Halal meat to them.

\title{
Health
}

On the other hand, there is a huge potential to tap the other non-Muslim community interests when it comes to food. Food, in general, is defined as anything eaten or taken orally to the body as a source of energy. Furthermore, the fact that food is a common need among people, the market potential is even more promising though people from different cultural backgrounds and religion have different perceptions and experiences of food. In today's society, the increasing concern over health promotes the acceptance of Halal food as it covers the whole understanding of consuming clean and hygienic food to promote better health. Consumers today are more aware of the importance of health thus influence their behavior on food consumption. They search for food that can keep them healthy and improve their mental state as well as their quality of life. In Islam, consuming Halal food constitutes an important aspect of the religion. The role of food in cultural practices and religious beliefs is complex but has a unified understanding among Muslim followers. For instance, the halal logo or label 
communicates and convinces Muslim consumers that the food product is produced and prepared according to the Islamic requirement. On the other hand, the non-Muslim consumers understand that food item carrying the logo are prepared in the most hygienic way and clean to be consumed. (N.M, Vloreen. Ardiana Mazwa Raudah binti Amir Abdullah, Siti Nurazizah binti Mohamad Ismail, 2014) Furthermore, it has also been proven that non-Muslim consumers do respond positively to Halal food certification (Siti Hasmah, Dann, Annuar, and De Run, 2009).

\section{Convenience \& Economic}

However, over the years, the demand of a proper government Halal certifications in a food product, restaurant or brand has made the price of the food product increases, due to the cost acquired in order to gain and maintain halal certification. In a perspective, a lot of Malaysian rely more on improper "Halal" label, mediocre "Halal" label, and presumptions or deductions of their views. This is especially when a restaurant, a product or a person selling it would have any resemblance or associated with Muslim identity. A restaurant with Quran verses hanging on their wall, a product with Arabic words or sentences, or a person selling the food product wearing a Fez or a Muslim robe. The presumptions are that the food, its preparation, and the final product is Halal in nature. Although Muslims Malaysians are much more educated, well versed with the surroundings scenario then they were 40 years ago in relation to halal food and resources. There are still many more Muslim Malaysians that have to rely on this presumptions due to the high price being imposed by Halal product. The income disparity in this case is getting wider since individuals or families with good income are able to purchase good quality halal food while those that are not, have to depend on improper "Halal" label, mediocre "halal" label and their presumptions of whether the food product is in the "Halal" circle.

A poultry product with a proper government "halal" certification would be more expensive rather than a poultry product being sold by a Muslim seller with no certification. However, there is a market for both of these options since there are families and individuals that can afford the first option and those that are unable to purchase it on a regular basis. Although consumers in general (Walley et al, 1999) and Muslims in particular, are increasingly concerned about the ways food is processed and the ingredients it contains, the real economic condition of the people makes them take the improper "Halal labels, mediocre "halal" label and presumptions steps rather than choosing the government "halal" certification. Food from the Middle East, which is perceived by many Muslims as possessing good, high-quality Halal values, will be more expensive to purchase once it has arrived on Malaysian's shore. These products will basically be purchased by those that are in the "more affordable" group of the Malaysian Muslims society. The majority of the Malaysian Muslims society will have to settle for the improper "halal" label, mediocre "Halal" label food or their presumptions of Halal food, restaurant or food handlers.

On the other hand, we have to understand that Halal accreditation is a must to ensure Muslims in Malaysia, a multiracial country gets its correct and proper food resources. However, in more than one circumstances, a properly halal labeled food will tend to be more expensive than those that are not. As a result, the halal market will be divided into those that can afford the price and those that go for other options. The other options refer to improper "Halal" label, mediocre "Halal" labeled and presumptions of the individual.

\section{CONCLUSION}

Malaysia's policy in Halal market has enable it to grow substantially with the help of private sectors and the expertise from many develop and developing countries. The existence of Halal 
Hub, global recognition of JAKIM certification and auditing, special tax incentives for Halal food production, double tax deduction of expenses for Halal certification, collaborating with international retailers and brands, halal cold storage and Halal express facilities, with the addition of Port Klang being Free Zone for Halal products fast tracked Halal certification approvals and its many well connected routes has created a great success story for Malaysia's halal sector. However, a good and contemporary understanding of the consumer acceptance, religious beliefs of other markets, the increase health concern of consumer, the convenience and economics of purchasing and consuming Halal products needs to be addressed, so that the success story can be prolonged and extended into another chapter of success and longevity of the Halal industry in Malaysia.

\section{References}

Abou- Youssef, M.M.H, Kortam, W., Abou-Aish, E. and El-Bassiouny, N. (2015), "Effects of Religiosity on consumer attitudes toward Islamic banking in Egypt", International Journal of Bank Marketing, Vol 33 No 6, pp. $786-807$.

Ariffin, A.S., (2007). Much ado about the Malaysian Halal food industry. The Halal Journal.

Beit Hallahmi, B. and Argyle, M. (1997), The Psychology of Religious Behavior, Belief and Experience, Routledge, London.

Eliasi, J.R. \& Dwyer, J.T (2002). Kosher and Halal: Religious observances affecting dietary intakes. Journal of the American Association. 102(7); 911-13

Fisher, J. (2012). “Branding Halal: A Photographic essay on global Muslim markets”, Antropology Today, Vol 28No 4, pp. 18-21.

Geser, H. (2009). "Work values and Christian religiosity”, Journal of Religion and Society, The Kripke Centre, Vol 11 , pp. 1-36

Grunert, K. G., Hartvig Larsen, H., Madsen, T. K., \& Baadsgaard, A. (1996). Market orientation in food and agriculture. Boston, MA: Kluwer.

Jamal, A. (2003. "Marketing in a multicultural world: the interplay of marketing, ethnicity and consumption:, European Journal of Marketing, Vol. 37No 11,pp.1599-620

King, M. (1967), "Measuring the religious variable: Nine proposed dimensions”, Journal of the scientific Study of religion, Vol 11 No 3, pp. 173-190.

King, M. and Hunt, r. (1972), Measuring the religious variable: replication”, Journal of Scientific Study of Religion, Vol 11 No 3, pp 240-251

Marzuki, S.Z.S., Hall, C.M., and Ballentine, W, P. (2012). Restaurant manager's perspectives on Halal certification. Journal of Islamic Marketing. 3(1); 47-58

MATRADE. (2011, January 26). Malaysia External Trade Development Corporation. Retrieved June 23, 2011, from Malaysia Halal Directory: http://www.matrade.gov.my

MATRADE, (2011, January, 26). Malaysia External Trade Development Corporation. Rertieved June 23, 2011, from Malaysia Halal Directory : http://www.matrade.gov.my

McDaniel,S.W. and Burnett, J.J. (1990), “Consumer religiosity and retail store evaluative criteria”, Journal of the Academy of Marketing Science, Vol 18 No.2 , pp 101- 112.

Muhammad, N., Norhaziah, Nuradli, R., \& Hartini, M(2007). Halal Branding: An Exploratory Research among consumers in malaysia. Available at nuradli.com.

O’Connell, B.J. (1975), “Dimensions of religiosity among Catholics”, Reviews of Religious Research, Vol 16, No 3, pp. 198-207

Piritta Lampila, Liisa Lähteenmäki, (2007) "Consumers' attitudes towards high pressure freezing of food", British Food Journal, Vol. 109 Issue: 10, pp.838-851,https://doi.org/10.1108/00070700710821368

Povera, A. (2010). “Tap big Halal Demand, SME players urged. Business Times

Razak, M. Najib (2010), keynote Speech at World Halal Forum 2010 in Kuala Lumpur

Rula M. AI Abdulrazak, Ayantunji Gbadamosi. “Trust, religiosity, and relationship marketing: A Conceptual overview of consumer brand loyalty", Society and Business Review, 2017. 
Said, M., Hassan, F., Musa, R., and Rahman, N.A. Assessing Consumers' Perception, Knowledge and Religiosity on Malaysia's Halal Food Products. Procedia, Social and Behavioral Sciences.

Singh, I. J., Sikhs and Sikhism ISBN 81-7304-058-3

Vloree, N.M., Ardiana Mazwa Raudah, A.A., \& Siti Nurazizah M.I. (2012) “Acceptance on Halal Food among NonMuslim Consumers. International halal Conference, PWTC, Kuala Lumpur, Malaysia.

Zainudin, A. (2017) "Halal Industry contributed 7.5\% to GDP in 2017, says DPM". The Malaysia Reserve. https://themalaysianreserve.com/2018/04/04/halal-industry-contributed-7-5-to-gdp-in-2017-says-dpm/ 